\title{
Extrusion and characterization of nanoclay filled polypropylene
}

\author{
Delva, L. ${ }^{a, b,{ }^{*}}$, Van De Keere, T. ${ }^{a}$, Alves, R. ${ }^{c}$, Ragaert, K. ${ }^{a, b}$, Gaspar-Cunha, A. ${ }^{c}$, Cardon, L. ${ }^{a, b}$, Degrieck, J. ${ }^{b}$ \\ ${ }^{a}$ CPMT group, Associated Faculty of Applied Engineering Sciences, University College Ghent, B-9000 Ghent, Belgium \\ ${ }^{b}$ Department of Materials Science \& Engineering, Ghent University, Technologiepark 903, B-9052 Ghent, Belgium \\ 'Institute for Polymers and Composites, IPC/I3N, Department of Polymer Engineering, University of Minho, Portugal
}

\begin{abstract}
A B S T R A C T
In recent years, the interest in nanocomposites has grown exponentially. However, the dispersion of polar nanoclay in an apolar thermoplastic matrix remains the key issue. In this manuscript, the process factors affecting the dispersion of nanoclays in a polypropylene matrix are studied. Both the processing of nanocomposites using twin screw and single screw extruders are compared. As the tensile properties of the material are influenced by the dispersion, these characteristics are used for a straightforward evaluation of the different processing parameters. The main goal of this study is to optimize the extrusion process parameters and to evaluate their influence on the strength properties of the material. Variations in properties were noticed for different screw speeds and for different compositions of the starting materials.
\end{abstract}

\author{
ARTICLE INFO \\ Keywords: \\ Nanocomposites \\ Polypropylene \\ Nanoclay \\ Characterization \\ *Corresponding author: \\ Laurens.Delva@ugent.be \\ (Delva, L.)
}

\section{References}

[1] Hussain, F., Hojjati, M., Okamoto, M., Gorga, R.E. (2006). Polymer-matrix nanocomposites, processing, manufacturing, and application: An overview, Journal of Composite Materials, Vol. 40, No. 17, 1511-1575.

[2] Kumar, A.P., Depan, D., Tomer, N.S., Singh, R.P. (2009). Nanoscale particles for polymer degradation and stabilization - Trends and future perspectives, Progress in Polymer Science, Vol. 34, No. 6, 479-515.

[3] Paul, D.R., Robeson, L.M. (2008). Polymer nanotechnology: Nanocomposites, Polymer, Vol. 49, No. 15, 3187-3204.

[4] Pfaendner, R. (2010). Nanocomposites: Industrial opportunity or challenge?, Polymer Degradation and Stability, Vol. 95, No. 3, 369-373.

[5] Varley, R.J., Groth, A.M., Leong, K.H. (2008). The role of nanodispersion on the fire performance of organoclaypolyamide nanocomposites, Composites Science and Technology, Vol. 68, No. 14, 2882-2891.

[6] Pavlidou, S., Papaspyrides, C.D. (2008). A review on polymer-layered silicate nanocomposites, Progress in Polymer Science, Vol. 33, No. 12, 1119-1198.

[7] Cauvin, L., Kondo, D., Brieu, M., Bhatnagar, N. (2010). Mechanical properties of polypropylene layered silicate nanocomposites: Characterization and micro-macro modelling, Polymer Testing, Vol. 29, No. 2, 245-250.

[8] Lee, H.S., Fasulo, P.D., Rodgers, W.R., Paul, D.R. (2005). TPO based nanocomposites. Part 1. Morphology and mechanical properties, Polymer, Vol. 46, No. 25, 11673-11689.

[9] Tjong, S.C. (2006). Structural and mechanical properties of polymer nanocomposites, Materials Science and Engineering: R: Reports, Vol. 53, No. 3-4, 73-197.

[10] Monticelli, O., Musina, Z., Russo, S., Bals, S. (2007). On the use of TEM in the characterization of nanocomposites. Materials Letters, Vol. 61, No. 16, 3446-3450.

[11] Palza, H., Vergara, R., Yazdani-Pedram, M., Quijada, R. (2009). Polypropylene/Clay Nanocomposites: Effect of different clays and compatibilizers on their morphology, Journal of Applied Polymer Science, Vol. 112, No. 3, 1278-1286.

[12] Santos, K.S., Liberman, S.A., Oviedo, M.A.S., Mauler, R.S. (2009). Optimization of the mechanical properties of polypropylene-based nanocomposite via the addition of a combination of organoclays, Composites Part A: Applied Science and Manufacturing, Vol. 40, No. 8, 1199-1209. 
[13] Cervantes-Uc, J.M., Cauich-Rodríguez, J.V., Vázquez-Torres, H., Garfias-Mesías, L.F., Paul, D.R. (2007). Thermal degradation of commercially available organoclays studied by TGA-FTIR, Thermochimica Acta, Vol. 457, No. 1-2, 92-102.

[14] Sichina, W.J. (2000). DSC as problem solving tool: Measurement of percent crystallinity of thermoplastics, Perkin Elmer Instruments, from http://www.perkinelmer.com, accessed June 27, 2012.

[15] Treece, M.A., Zhang, W., Moffitt, R.D., Oberhauser, J.P. (2007). Twin-screw extrusion of polypropylene-clay nanocomposites: Influence of masterbatch processing, screw rotation mode, and sequence, Polymer Engineering \& Science, Vol. 47, No. 6., 898-911, doi: 10.1002/pen.20774.

[16] Dolgovskij, M.K., Fasulo, P.D., Lortie, F., Macosko, C.W., Ottaviani, R.A., Rodgers, W.R. (2003). Effect of mixer type on exfoliation of polypropylene nanocomposites, In: Proceedings of ANTEC conference, Nashville, 2255-2259.

[17] Kubišová, H., Měřínská, D., Svoboda, P. (2010). PP/clay nanocomposite: optimization of mixing conditions with respect to mechanical properties, Polymer Bulletin, Vol. 65, No. 5, 533-541.

[18] Joshi, M., Viswanathan, V. (2006). High-performance filaments from compatibilized polypropylene/clay nanocomposites, Journal of Applied Polymer Science, Vol. 102, No. 3, 2164-2174, doi: 10.1002/app.24179.

[19] Kohlgrüber, K., (ed.). (2008). Co-rotating twin-screw extruders: Fundamentals, technology, and applications, Carl Hanser Verlag, Munich.

[20] Hoagland, D. (1997). The physics of polymers: Concepts for understanding their structures and behavior, by Strobl, G.R., Springer-Verlag, New York, 1996. ISBN 3-540-60768-4, Journal of Polymer Science Part A: Polymer Chemistry, Vol. 35, No. 7, 1337-1338.

[21] Callister, W.D. (1997). Materials science and engineering: An introduction, John Wiley \& Sons.

[22] Ellis, T.S., D'Angelo, J.S. (2003). Thermal and mechanical properties of a polypropylene nanocomposite, Journal of Applied Polymer Science, Vol. 90, No. 6, 1639-1647.

[23] Bandyopadhyay, J., Ray, S.S. (2010). The quantitative analysis of nano-clay dispersion in polymer nanocomposites by small angle X-ray scattering combined with electron microscopy, Polymer, Vol. 51, No. 6, 1437-1449.

[24] Masenelli-Varlot, K., Vigier, G., Vermogen, A., Gauthier, C., Cavaillé, J.Y. (2007). Quantitative structural characterization of polymer-clay nanocomposites and discussion of an "ideal" microstructure, leading to the highest mechanical reinforcement, Journal of Polymer Science Part B-Polymer Physics, Vol. 45, No. 11, 1243-1251.

[25] Xie, S., Harkin-Jones, E., Shen, Y., Hornsby, P., McAfee, M., McNally, T., Patel, R., Benkreira, H., Coates, P. (2010). Quantitative characterization of clay dispersion in polypropylene-clay nanocomposites by combined transmission electron microscopy and optical microscopy, Materials Letters, Vol. 64, No. 2, 185-188.

[26] Yang, Y., Chen, J., Yuan, Q., Misra, R.D.K. (2011). Structure-property relationship in impact modified nanoclayreinforced polypropylene, Materials Science and Engineering: A, Vol. 528, No. 3, 1857-1863. 